\title{
Freedom of Conscience is Freedom of Choice: Women's Reproductive Needs, Rights, and their Therapeutic Implications
}

\author{
Carlos M. Del Rio \\ Southern Illinois University, Carbondale, USA \\ Email: delrio@siu.edu
}

Received June 28 ${ }^{\text {th }}, 2012$; revised July 30 ${ }^{\text {th }}, 2012$; accepted August $12^{\text {th }}, 2012$

\begin{abstract}
Using reasonableness, we examine the U.S. Catholic bishops' opposition to provisions of the Affordable Care Act of 2010. Weaving contributions from theology, philosophy, and jurisprudence, we emphasize the reasonable importance of mental health therapy for women within a relevant Catholic/Christian dialogue, particularly in the wake of the U.S. Supreme Court's decision on healthcare. We principally identify socially imbedded factors that contribute to ending unwanted pregnancies, and argue that freedom of conscience is indeed freedom of choice within which women's reproductive needs lie under protections of the U.S. Constitution. We recognize that Catholic tradition originates in the words and behaviors of Jesus. Examining closely these actions toward women, we find no reasonable justification for the bishops' position against women's freedom of conscience. We also discovered that revelation does not belong exclusively to the bishops; truth continues to be revealed to all human consciences, and true freedom does not allow for coercion/castigation of dogmatic import. We advocate for women's ability to openly discuss their struggles to meet their reproductive condundra and to deconstruct their sexual stereotypes in mental health therapy. We provide crucial recommendations to augment choices for women's reproduction conundra, and incite the need for new epistemic frameworks to address the complexity of female sexuality.
\end{abstract}

Keywords: Freedom of Conscience; Freedom of Choice; Women’s Reproductive Needs; Healthcare Provisions; Constitutional Protections

\section{Synoptic Context and Purpose}

The proposition that "all men are created equal" means that all persons share an intrinsic human dignity and worth (Hennette-Vauchez, 2011). It means persons have natural autonomy which enables each to make decisions and to come together to form lasting relationships, and communities. It means their personal and communal interactions carry a sense of fairness and retribution. And as individuals contribute to their communities, their communities protect their equality and their needs. In principle, these are the essential characteristics of civil society in our country.

Worldwide communities have recognized fairness and retribution as constitutive of the reciprocity between persons and their common good whether regional or global. These attributes are essential to ethical principles (of respect, autonomy, justice), and to jurisprudence (Torfs, 2011). Yet, because doing what is ethical does not mean of necessity doing what is legal, and vice versa; we suggest the nexus between these areas is doing what is reasonable (that which is not intrinsically contradictory in a logical sense). Simply proposing that all persons are "created equal", as human beings, does not capture the needs that distinguish their sexes. For example, men and women have different biological and health needs, particularly in terms of reproduction. They also have different ethical responsibilities emerging from these sexual needs. Working complementarily to one another among sexes is therapeutically and socially desirable. It is unfortunate, however, to observe that when men and women fail to understand one another, imbalances occur and one sex usually oppresses the other. As we intend to explain below, sex (gender) politics and its social consequences have been deleterious to women's sense of sexual freedom
(John Paul II, 1995: § 3). Ethical advocacy compels us ${ }^{1}$, as mental health therapists, to analyze how gender divisions supersede fairness and retribution in our society.

With a compelling social interest, the Obama administration enacted into law the Patient Protection and Affordable Care Act of 2010 (House Office of Legislative Council, 2010). Its implementation will go into effect in August, 2012. One of its main effects is the provision of preventive healthcare for women's reproductive needs. This legislation originally required employers to absorb the cost of these preventive services, but it met opposition from religious leaders, particularly from the U.S. Catholic bishops (Ad Hoc Committee for Religious Liberty [AHCRL], 2012).

The U.S. Catholic bishops claimed magisterial authority to speak for "all" Catholic women, and, indeed, in the stead, of "all” religious women in America against the provision of contraceptives, abortifacients, and sterilization (AHCRL, 2012). The bishops invoked religious freedom in a civil society against provisions of the Affordable Care Act of 2010. The Obama administration, in turn, accommodated this religious objection and placed the responsibility on insurance companies (instead of religious employers) so that women could receive comprehensive healthcare at no cost (Federal Register, 2012). Yet, unsatisfied with this accommodation, the U.S. Catholic bishops designed a two-week campaign, the Fortnight of Freedom, be-

\footnotetext{
${ }^{1}$ Using editorial "we" is not encouraged in scholarly works. However, because I wish both to engage the reader and speak as a mental health therapist, my presumptions are (a) that the silent reader's pronoun and mine will fuse into "we" and "us" and "our" and (b) when I refer to mental health therapists I wish to speak as one with all professionals who care for the human psyche whether they may be counselors, social workers, psychologists, psychiatrists, physicians, and so on.
} 
tween 21 June 2012 and 4 July 2012 to stand against this "governmental intrusion" that threatens their religious convictions against birth control from contraception to abortion (Otterman, 2012). The bishops argued that the legislation's provisions are unconstitutional (AHCRL, 2012). Most interesting is to realize that this campaign coincides with the U.S. Supreme Court's decision on the constitutionality of the Affordable Care Act of 2010 (see footnote nine).

Here, we focus on the group that remains voiceless (American women) and attempt to interpret their experiences based on germane statistics. A scrutiny of preeminent publications that helped shape family therapy since its beginnings in early 20th century American culture revealed an absence of publications regarding women's reproductive needs. More specifically, we conducted a search in the Journal of Marital and Family Therapy (from the American Association for Marriage and Family Therapy), The Family Journal (from the International Association of Marriage and Family Counselors), and Family Process (from the Family Process Institute) concurrent with the Obama administration between 2008 and 2012. We not only looked at each article published in these sources over the last four years, but we also conducted searches within the same publications regarding: birth control, contraceptives, abortifacients, abortion, family planning, and Catholic Church. We used EBSO Academic Search Premier to search these terms as: subject matters, words within abstracts, and key words authors provided for publication; and our results confirmed an absolute absence of literature on these matters.

We did find specific publications from other areas of science that inform the current discourse on reproductive matters. Hence, we decided to commence a dialogue on the ethical, clinical, and theoretical implications that these matters may beget for mental health therapists, particularly those dedicated to serving couples and family clients. A sense of professional advocacy and ethical principles of welfare and no harm, justice, autonomy, and loyalty provide impetus to our discussion.

We intend to address these reproductive matters within a Catholic framework given that the same hierarchy's actions and epistemic perspective have opened the door for this discussion. We embrace reasonableness to engage in this discussion. This requires contributions from theology, philosophy, and jurisprudence germane to Catholic epistemology. We hope to achieve clarity as we draw language from each of these disciplines.

At the outset we recognize that pregnancies ought to end in childbirth, and that fertilized human ova not only require male chromosomes but also never become trees, rocks, or artefacts (from Latin artefactum, human made), but human persons. However, establishing a person's right to life entails other protections to sustain such life; allowing life to merely exist does not guarantee its quality as life but renders human existence as mere survival. However, the ability to freely make decisions about birthing new life and sustaining such new life is indeed women's major contribution to the common good, but we sustain that women's ability to bring life forth must also be balanced with their ability to make personal or professional contributions to society (Mortensen, Torsheim, Melkevik, \& Thuen, 2012; John Paul II, 1995, § 3, 12).Thus, we examine the reasonableness of the U.S. Catholic bishops' opposition to preventive healthcare for the reproductive needs of women. And we strongly emphasize that the bishops have never spoken so openly and with equal force about unemployment, illiteracy, lack of health services, poverty, unequal income earnings, un- stable lasting relationships, dysfunctional partnerships, special needs, economic recession, familial disruptions from the war on terror, violence whether emotional, psychological, or physical; and many other factors that have thwarted women's ability to make free decisions about their reproductive and healthcare needs and those of their offspring, whether that same offspring may be unwanted, mistimed, or unplanned.

\section{Preventive Healthcare versus Abortion Incidence}

The first decennial census data of the 21st century revealed that of every 10 Americans, 6 are female and 4 are male. And $20 \%$ of 308.7 million Americans are females of reproductive capacity between 15 and 44 years (62.4 million). However, only about one in every 10 Americans is a female of legitimate reproductive capacity (ages ranging from 20 - 39 years; 41.1 million). Data groupings at every four years do not allow for ascertaining how many of these women (41.1 million) were sexually active either in a "marriage" or in a heterosexual relationship, or how many women were specifically 18 and older (U.S. Census Bureau, 2012a). Yet, these 41.1 million women's reproductive potentials (presuming 100\% are fertile) seem to be the U.S. Catholic bishops' major concern regarding preventive healthcare services.

We turn to religious adhesions to comprehend the extent of women under the bishops' magisterial authority. The most recent American Religious Identification Survey of 2008 (U.S. Census Bureau, 2012b) proved statistically representative of the American population (two years prior to the census). This survey identified $76 \%$ of Americans were Christians, and $25 \%$ were specifically Catholic. Applying these rates to the census data, it is probable that about $12.5 \%$ of Americans in 2010 were female Catholics, and twice as many were Christian but not Catholic.

We must emphasize that women are primarily females and then religious regardless of denomination. As females, women are sexual beings and their sexual expressions must remain their own free choice. We also posit that women wish to avoid pregnancies rather than terminate them once they have begun (Dixon \& Nussbaum, 2011). However, birth control historically includes abortion incidence despite efforts to increase the effecttiveness of contraceptives, and abortion incidence is a more direct result of depriving women of contraceptives. It is most surprising to realize that almost $50.0 \%$ of all pregnancies in America are unintended ${ }^{2}$, and that an alarming $40.0 \%$ of all unintended pregnancies end up in abortion. Said differently, of every 10 pregnancies, 5 are unintended, and of these, about 2 end up in abortion. At a national scale, these rates represented 1.2 million abortions in 2008. Of these many abortions $37.0 \%$ of the participating women were Protestant, and $28.0 \%$ were Catholic (Guttmacher Institute, 2011). These data do not account for the religious affiliation of these women's male counterparts. Left with only female statistics, a couple questions arise: What reasons pressure women to seek abortions? And what sort of female profile

\footnotetext{
" "Unwanted" pregnancies include those that happen when women did not want them neither at the time they occurred, nor at any time in the future. "Mistimed" pregnancies are those that happen when women would welcome them some time in the future, but not when they happened. And "unintended" pregnancies are those that are either unwanted or mistimed (Wildsmith, Guzzo, \& Hayford, 2010). Human reproduction's complexity includes also embryos lost before implantation, at a probable $50.0 \%$ rate according to biologists' estimates (Cornwell, 2001).
} 
emerges from abortion incidence?

\section{Reasons to Seek Abortions}

Laws do not prevent abortion; contraceptives prevent abortion (Shah \& Ahman, 2009). In fact, in other societies where abortion is lawful it is negatively correlated with its incidence (Potts, 1967). This negative correlation is reasonable because where contraceptives are available, abortion incidence decreases. By contrast, unwanted pregnancies lead to increased abortion incidence. And women's choices include their own sense of self-efficacy: whether they believe they are ready or able (in cases where children already exist) to care for their children. What is most disturbing is that women who seek abortions have reported some overpowering reasons that include: (a) pressure from boyfriend, husband, parents, extended family, friends; (b) un-readiness to start or expand their families due to already existing responsibilities; (c) experience serious medical problems or learned their fetus has severe abnormalities; (d) experience personal crisis; (e) experience religious or social stigma usually in the form of persistent guilt or shame; (f) failed contraceptives or non-use of contraceptives due to chosen or imposed religious beliefs; (g) lack marital status, separated, divorced, widowed; (h) inability to support or care for a child; (i) pregnancy resulted from rape or incest; (j) interference with career or education plans; $(k)$ live in abusive relationships where victimization led to pregnancy; (l) fear of physical abuse from parents/partners; and (m) fear of being ejected from their family home due to pregnancy (Dudley, 2003; Finer, Frohwirth, Dauphinee, Singh, \& Moore, 2005). These reasons necessitate no commentary. Instead we only report them for reflection.

\section{Composite Female Profile}

All religious denominations are represented in women who engage in contraceptive practices, and, at times, in abortion. However, abortion incidence includes primarily young women, unmarried women, racial minority women, women living in poverty, and women whose education is limited (Dudley, 2003). This composite profile does not only exclude their male counterparts but it does emphasize women's dispossession and powerlessness. These women do not have open access to contraceptives, and if they do, they do not have the experience to use them, or fail to use them for fear of religious damnation added to their religious sense of sexual guilt (Yip, 2010).

\section{Other Contributing Factors: Women's Inequality}

Women have practiced birth control methods since antiquity (Bujalkova, 2007; Joffe, 2009). These methods have ranged from coitus interruptus to infanticide predominantly of neonate females, and males with perceptible congenital malformations. Abortion incidence was also a part of birth control practices in ancient cultures ${ }^{3}$. Women cared for women, unless women were wealthy in which cases male physicians tended their re-

\footnotetext{
${ }^{3}$ Birth control has also favored historically the birthing of males over females. This preference for male heirs was to ensure the political control of regions, countries, kingdoms, and empires. In this way, a tacit notion of patriarchy has remained embedded into the cultural fabric of societies. These attitudes that have favored males over females have been preserved through the centuries unto contemporary social groups across cultures. These phenomena manifest themselves in terms of gender stereotypes, by which motherhood is conflated with womanhood (Cuzack \& Cook, 2009).
}

productive needs. Historians have documented male knowledge of female bodies that is not exclusive of those who inhabit female bodies (Bennett, 2008; Green, 2008). In fact, beginning in the Dark Ages and moving into Modernity, a male dominance in obstetrics became prominent in England and in the U.S. (Green, 2008).

Whereas birth control methods would seem to be a female content area, birth control has been subsumed to male dominance. These methods comprise from contraceptives, to abortifacients, to abortion in contemporary societies. But access to these preventive methods (excluding abortion) is determined in great part by political agendas that shape legal frameworks that either allow or disallow women to access them. However, the responsibility for human reproduction is placed on female sexual partners, with total disregard of the male co-participants in these processes whether their co-participation may be genital or detached by virtue of reproductive technologies. Thus, women remain relegated as responsible for birth control methods, but truly they are not allowed complete autonomy over reproductive decisions.

As a result, if women seek abortion to end their pregnancies, it is not only a personal moral issue, but (also) abortion per se is a social, cultural, legal, and political conflict that needs to be addressed communally because women do not conceive alone; nor should they be responsible for the material costs of motherhood (Jesani \& Iyer, 1993). Ideally societies ought to recognize that the care of children is a communal responsibility, but women have been historically subordinated to male leadership and economic solvency regarding reproduction policies and preferential male progeny.

\section{Material Hardships}

Women who earn incomes lower than men strive to meet their basic needs. And when children suffer material hardships, societies (and bishops) ought to do something to end these hardships. The crude reality is that no one cares when women or children suffer the visible and not so visible signs of privations in our society or in other societies. People are not usually magnanimous to the necessitous.

Material hardships may be either critical or serious. If critical, individuals struggle to meet their basic needs. If serious, individuals lack "goods, services, and financial ability to maintain employment and a stable, healthy home environment" (Boushey \& Gundersen, 2001: p. 20). Usually, income, education, and family composition are variables associated with material hardships (Heflin \& Butler, 2012). For example, women who enter into material hardship have more children in their homes. These same women suffer poor health and domestic violence, and their food insufficiency is associated to lower income and lower education (for detailed statistics on material hardship, see Heflin \& Butler, 2012).

Many women of reproductive age survive at a level of material hardship in our society. These women have to make tough decisions to control their reproductive capacities, and it should not be surprising to anyone that some of these women have to choose to end their pregnancies because of their overpowering material hardships.

Where do material hardships come from? Are they the byproduct of young, promiscuous, females? Or are they, perhaps, the results of stronger variables that have been imbedded in the fibers of human societies? No one can deny that women earn less than men in equal positions and with equal educational back- 
grounds. No one can deny that women are presumed responsible for childrearing responsibilities. No one can deny that women have historically been diminished as sexual objects. No one can deny that there is female sexual trading which uses drugs to ensure women's dependency on their handlers. To compensate for these social variables, it is imperative to protect women's right to control their natural ability for reproduction. This means that ideally women must not be forced to make choices (or choose from lesser alternatives) that violate their consciences, such as in the case of critical or serious material hardships. In this sense the conscience that must be protected belongs to voiceless women in our society.

\section{Gender Stereotyping}

Human sexes seem to have been created to preserve their species (Genesis, 1: 27-28; New International Version). This presumes heterosexual sharing of chromosomes is essential to preserve humanity, albeit methods of procreation have advanced to the extent that coitus is only sufficient and no longer necessary for human fertilization. Reproductive technologies have recast the notions of fertilization and of motherhood. For example, in vitro fertilization and surrogate uterus usage have supplanted the "biological" notion of motherhood.

Notwithstanding advances in reproductive technologies, historical records evince that women have been linked to motherhood and that they have been perceived socially (and "by divine ordinance") as necessary "vessels" for human procreation (e.g., Bradwell v. Illinois, 1872: pp. 137-138; John Paul II, 1988: § II.3). This is an example of how embedded gender stereotypes remain in our culture, attributing to women certain roles or functions by reason of their sexuality. As a result, women have been stereotyped primarily as mothers (Cusack \& Cook, 2009). Motherhood, thus, places on women but not on men the expectation to "prioritize childbearing and childrearing over all other roles they might perform or choose" to perform during their life-times (Cusack \& Cook, 2009: p. 57).

Perhaps gender stereotyping ought to provide women with recognition and deference (John Paul II, 1988, § II.4). By contrast, gender stereotyping has subsumed women's autonomy to men's autonomy in social, political, and religious contexts. For example, women have also been stereotyped as "weak and vulnerable", and as "incompetent decision makers" (Cusack \& Cook, 2009: pp. 55-56). The former cements the legal fiction that women need laws and restrictions to protect them from themselves. The latter renders women as irrational and devoid of an inherent capacity for moral agency, thus, justifying the denial of birth control methods and family planning decisions.

When gender stereotypes become part of our cultural beliefs and behaviors, women are put at a disadvantage and their ability to exercise their freedom is nullified either overtly (by means of laws or religious dogmas) or covertly (by means of adopting social practices that are so autonomous that they become second nature and are not questioned or challenged). In the end, once gender stereotypes are in place, they become very difficult to be eliminated or changed (Cusack \& Cook, 2009). We believe gender stereotyping must end lest women be denied their natural equality to men from ethical and legal perspectives.

\section{Freedom of Conscience is Freedom of Choice}

Freedom is essential to human will. We adduce that free will is the ability to choose among alternatives without constrains, even at the level where alternatives may be reduced to the point that they may seem not to exist (Svetlichny, 2012)—-this is the major argument of determinism, ${ }^{4}$ to place causality for one's choices on outside factors, thus denying human agency. With few denominational exceptions (e.g., Lutherans and Calvinists during the Reformation era) free will remains consonant with Christian perspectives of human agency (Fischer, 2010). Free will infuses human agency with moral value, because one's free willful choices are always for the purpose of doing something. As a result, human actions build upon one another, and their purposes and their consequences define the moral character of each person. Human agency rests upon a sense of ought-ness that requires each human being to wonder: What am I to do? Who am I to become?

Ancient accounts of creation, including the Jewish story in Genesis, make allusion to the human ability to make free decisions as a gift that renders them in close likeness to their Creator/s (O’Brien \& Major, 1982). The tacit argument in these stories posits that if God is perfect and good, God has to respect human's free will; otherwise if God took away human free will, then God would not be perfect and good. And this is an illogiccal conclusion. This is not acceptable in monotheistic religions.

Said differently, God is self-sufficient and completely perfect and good. God creates out of goodness, and God's perfection is reflected in the created order. In this creatural realm, human beings are similar to God because they have intelligence (which seeks goodness and truth) and the ability to make free choices, the ability to choose among alternatives for the purpose of doing something or of becoming a particular kind of someone (Wertenbroch, Vosgerau, \& Bruyneel, 2007). In contrast, if God controlled all humans' actions, all the time; then, there would be no goodness in God, nor would there be perfection reflected in humans' ability to make free choices. There would simply be no point to human existence granted that whatever one were supposed to do or to become were already predestined. If this were the case, and because God is all good and perfect, then human beings would be always good and always perfect. There would be no room for morally negative actions, but because we experience morally negative actions or consequences of such actions (Gisin, 2010), it follows that God does not control humans' free will at all.

In this sense, God is pro-human-choice-because God respects (out of God's own perfection) every human choice that has ever taken place or will yet take place. God's omniscience does not cancel out the human ability to decide one's future by the choices and actions in which one engages presently (e.g., Rhoda, 2007).

Freedom of conscience is pre-required for free will to infuse

$\overline{{ }^{4} \text { It would be impossible to consider all possible arguments about free will }}$ and determinism in this discussion. Suffice it to say that if all human actions were truly determined by factors outside human control, this reasoning would go on ad infinitum, but this would simply be a logical fallacy because at some point in time someone had to make a choice to do something to set all causal factors in motion. Further, if human agency were not existent, then moral responsibility would not follow, and the notion of hell, for example, would either be non-existent or God would be unjust for allowing people to choose hell through habitual actions, or habitual mindsets. Even though we have no concrete evidence of hell, we have concrete evidence of morally evil actions in humanity's history. And moral evil is the result of human agency (see Grisez, 1983, for a greater explanation of these complex moral views). And because moral responsibility follows moral actions, we conclude human agency's existence. We encourage readers to become familiar with other philosophical positions including Determinism, and Compatibilism. Here, we only touch briefly on free will because it is consistent with Christianity. 
human agency. It is within one's conscience that one is able to capture goodness as truth; we become aware of what is intrinsically right or wrong. And the discernment that each person invests in making decisions is procedural in nature (no matter how small is the time it takes within one's conscience-this time may be so minute that the process may seem either spontaneous or simultaneous to a person's actions). And the choices that the person makes, which are further, conveyed through explicit actions must also carry the same free nature.

In consequence, echoing moral scholars, freedom of conscience is truly freedom of choice: It is the ability to decide and to act as one pleases (Paul VI, 1965: § I.1; Grisez, 1983). Free will is not an ontological reality, but an epistemic process of moral consequences. And the actions that human agency makes manifest may be indeed perceived as ontological realities.

The intrinsic human right to liberty is meant to protect every person's ability to agency, the exercise of her free will. Societies implement legal frameworks to protect and to ensure each person's ability to choose from available alternatives without constrains. Yet the development of legal enactments and case law (judicial decisions) tend to follow interactional patterns of what works for individuals within societies (Katz, 2011). In this sense, insofar as an unfair distinction between the sexes remains in our culture; a lawful procuration of personal rights remains untenable. For example, it is possible to establish a person's right to life while simultaneously allowing lawful practices that may render that same person's life a mere survival experience, full of material hardships, disabilities, or other conditions that would render that person's pursuit of "happiness" untenable.

More specifically, despite the deplorable conditions in which women strive to plan their families and manage their reproduction capacities, at times opting to end unwanted pregnancies; influential (Christian) groups have compounded to the difficulties women face when seeking safe abortions by supporting the enacting of laws that would expose women to: (a) unwanted vaginal probing prior to abortion (at their expense), (b) images of their unborn fetus, (c) ultrasounds that would display heart activity in the pre-aborted fetus, and (d) increasing taxes on those who seek abortion. Worse yet, American pro-lifers have argued that to overturn access to abortion, two goals must be achieved. One, the definition of person must be recast to include unborn human beings, and, two, more conservative judges must be appointed to the Supreme Court (Potts, 1967) ${ }^{5}$. We leave the reader to draw her own evaluations on whether these initiatives substantiate the notion of a civil society in which freedom to choose is considered to be a constitutional right for all.

In the case of women's reproductive needs and their health coverage, the U.S. Catholic bishops' challenge has rested on the notion of cost. To which the Obama administration accommodated the right to conscientiously object to pay for birth control provisions by religious employers because the bishops rejected to pay for these provisions for women in their employment. As a result, the administration shifted the responsibility to insurance providers so that women's reproductive healthcare needs would meet licit coverage. This means the U.S. Catholic bishops' campaign against the administration is not based on the constitutional protection of freedom to choose without constrains in a civilized society. It began as a denial to pay for the costs of birth control methods germane to women's sexuality (Eisgruber \& Sager, 2007). It has taken on the impression of religious freedom to allow for their magisterial authority to dictate what is sexually acceptable of women's sexuality and to disallow women to make free choices as matters of their individual consciences as persons and as citizens (Katz, 2011). This position is inherently contradictory and thus unreasonable. It is an epistemic dichotomy.

\section{Free Will Constrained}

Dignitatis Humanae (Paul VI, 1965b) defined religious liberty simply as "immunity from coercion in civil society" so that each person may act of her "own judgment, enjoying and making use of a responsible freedom” (Paul VI, 1965b: § I.1). This declaration exhorted governments to establish legal frameworks to protect religious freedom, which requires theological freedom. Herein lays the challenge of religious liberty: The U.S Catholic bishops wish to ensure freedom from coercion in civil society, yet they also coerce those who believe in God to follow their claim for an all-encompassing magisterial authority in matters of human reproduction. In this sense, one's freedom to choose becomes a predicate of what the bishops define as sexually acceptable belying the ontic diversity of sexual identities and heterosexual practices.

The bishops are called to serve the ecclesia which is composed of each and every one who assents to God's revelation in the person of Jesus (Matthew 20: 26-27). Yet the Catholic magisterium leaves no room for any individual to exercise her conscience absolutely and freely (Paul VI, 1965b: § II. 3-4), especially regarding religious matters relative to the person's own sexuality. As a result, people live with a sense of fear of facing excommunication, the denial of sacraments ${ }^{6}$ because of the limited alternatives from which individuals ultimately make choices regarding their reproduction. How is then each human

\footnotetext{
${ }^{5}$ When this writing began in April, 2012, one question remained unanswered: What about the dates the bishops have selected to campaign agains the Affordable Care Act of 2010? It has become clear that the U.S. Supreme Court is deliberating on the constitutionality of this legislation based on its mandate to purchase insurance coverage, which would require religious followers to pay the cost of services relevant to the reproductive needs of women, particularly the provision of abortion, according to some arguments (Anderson, 2011; Reinhardt, 2012a, b). So it seems that the bishops' insistence to protect religious liberty has become an accountancy dispute for the ulterior motive of instilling their magisterial authority in sexual matters. The Supreme Court is composed of five Republican appointed justices and four Democratic appointed justices. Should political views cloud issues of law and constitutionality? Better yet, should issues of freedom and conscience protection become expenditure matters? It remains to be seen how the justices would rule on the healthcare mandate and germane questions (Rovner, Totenberg, \& Frick, 2012). However they may rule, this article remains timely to address the reproductive needs of women openly in therapeutic encounters (unless a lack of diagnostic code for such endeavor may render such conversations uncoverable and illicit). We know for example that inside trading in the U.S. markets is illegal. Yet, it seems (comparable to inside trading) the bishops have had inside knowledge that benefits them. First, their concern for religious liberty began when Benedict XVI alluded to threats to freedom ex cathedra. Second, the president of the U.S. bishops commenced his declaration against women's reproduction choices, as the last consistory (of cardinals) was in the making; earning him and some other prelates hierarchical promotions. Third, the bishops have had inside knowledge of the chief justice's efforts to have the Supreme Court rule on the healthcare law within the period the bishops have called Fortnight to Freedom. Doubtless the Supreme Court's decision on the challenges that have been raised against healthcare provisions will impact the nation's interest to provide comprehensive healthcare to individual citizens (Rovner, Totenberg, \& Frick, 2012). Yet, the bishops’ efforts to influence the highest court of the land must not stop our efforts to advocate for women as persons and citizens entitled to constitutional protections regarding freedom of conscience, which imbues freedom of choice.
} 
person expected to act of her own judgment and free will from any coercion if freedom suddenly is predicated upon the bishops' magisterium? ${ }^{7}$

Humanae Vitae (Paul VI, 1968) came to light against recommendations from the committee that participated in its preparation/redaction (Greeley, 1979). Humanae Vitae essentially posits that all forms of birth control (contraception and abortion) are moral evils, and that all coitus must be open to procreation, and denies the possibility of coitus outside marriage. Procreation then is the proper end of conjugal coitus, not pleasure.

However ethically desirable Humanae Vitae's universal axioms may be they remain untenable and contrary to current sexual practices. For example, the axiom that "all conjugal coitus must remain open to procreation" finds no absolute ontological corroboration because not all heterosexual coitus are capable of procreation, sexual pleasure also brings couples together in intimacy; and, not all sexually active couples are married, able to marry, or wish to be married; or are willing to procreate. As a result, Humanae Vitae has met several Catholic groups' dissent, yet it remains the official position on conjugal sexuality. But perhaps the most damaging aspect to the universal procreation axiom is the endorsement of "natural family planning”, , the only acceptable form of birth control the bishops recognize and encourage.

Evangelium Vitae (John Paul II, 1995b) demanded respect of every human life because every human life is the proper object of God's love, particularly the lives of the poor, the weak, and the defenseless. And whereas Evangelium Vitae denounced abortion and other forms of ending life once begun, it recognized that in some situations where individuals experience insurmountable pressures and choose to end life, these very conditions diminish the moral responsibility of the "coerced" or limited choices under which individuals make morally wrong choices $^{9}$. As a result, and not content with these social pressures (which are the true essence of a culture of death), Evangelium Vitae demanded everyone's commitment (including the bishops') to promote just legislation to alleviate the conditions that pressure individuals to end lives, insisting that a lack of inherent fairness (among the sexes) would place the will of the stronger (the rich and, perhaps, influential Christians) over and above the rights of individuals, particularly the poor, the weak, and the defenseless.

\footnotetext{
${ }^{6}$ The bishops claim their authority to deny sacraments is rooted in ecclesiastical tradition. In contrast, tradition originated with Jesus' mandate to give freely what they freely received (Matthew 10: 8). In this sense, the bishops have no authority to deny sacraments to anyone, because they did not generate the sacramental grace that Jesus freely intended for all human beings. ${ }^{7}$ Magisterial authority is presumed infallible (incapable or error). By contrast, history has evinced that papal positions have contradicted one another. The fallacious nature of infallibility rests on its disjunctive implications: either something is infallible or it is not. And historical evidence has proven that the church's teaching authority is not always infallible (Pham, 2004). Hence, magisterial authority is not infallible; infallibility is thus logically false.

${ }^{8}$ This absolute axiom: "all coitus must be open to procreation" is contradicted by the simultaneous endorsement of natural family planning. Natural family planning is a birth control method perhaps no different than coitus interruptus. The former allows ejaculations only during periods of time when no ova are present; the latter allows for ejaculations outside the uterus to prevent sperm to reach ova when present. The former is acceptable because ejaculating inside the uterus would appear that that particular ejaculation took place in an environment conducive to procreation despite the fact that it was "intentionally" done when no ova were present for procreation to occur. But the latter comprises the equivocal intentionality; both prevent fertilization of ova.
}

According to census data, only minority births increased in the U.S. population by 1.9 percent to 114.1 million or $36.6 \%$ of the total U.S. population (FoxNews.com). Several questions (open for discussion) arise from these data. Are minority women more fecund than white ethnic women? Or is it that minority women have more restricted access to birth control methods than white ethnic women? Do papal restrictions on birth control only apply to minority women? Doubtless many perspectives may provide diverse answers to these questions. However, mental health therapists must address these questions. Including for example: How to address the sense of guilt and shame that may accompany women for engaging in conscious choices that on first sight appear to defy bishops? How can we best serve the presenting emotional disturbances, mood disorders, and other comorbid conditions following abortion (Charles, Polis, Sridharab, \& Blum, 2008; Coleman, Coyle, Shupin, \& Rue, 2008; Major, Applebaum, Beckman, Dutton, Russo, \& West, 2009; Kimport, Foster, \& Weitz, 2011)? Where, when, and how must women speak openly about the factors that are concomitant to the gender stereotypes that women face as wives, mothers, sisters, daughters, citizens, and persons?

\section{Therapeutic Implications}

As the U.S. Catholic bishops insist on religious freedom to further perpetuate the stereotype of women as primarily mothers, this insistence coerces women's freedom to choose childbearing and childrearing, regardless of whether they wish to be mothers, or professionals, or simply dignified individual persons.

From the data that are available, it is clear that minority, young women with minimal education face the most challenges regarding their sexual expressions. As mental health therapists, we must speak for these voiceless women and interpret their message both in academia and in the therapeutic encounter. Women must learn about their nature, their dignity, their limitations, and their potentials. Certainly feminist perspectives have emerged to modify our perceptions of women. But this fact must not prevent all mental health therapists and scholars to continue to be open about these concerns that must be addressed everywhere. We must learn from the bishops to speak about women's freedom strongly, assertively, but without self-serving motifs.

The bishops' magisterial authority originates in scriptures, revelation, and tradition; summarily, in the words and actions of Jesus. We must then as professionals become aware of the historical importance of how Jesus treated women. From a Christian perspective both the birth and the resurrection of Je-

\footnotetext{
${ }^{9}$ Moral complicity is diminished in proportion to available alternatives for choices; that is to say, people who face limited alternatives to make morally questionable choices face lesser moral consequences. For example, this principle of moral proportionality applies to Joseph Ratzinger's complicity when he was "forced" to join Hitler's Youth, and repaired war airplanes. If these repaired-airplanes were then used to kill other human beings, Ratzinger's contributing "forced-repairs" would face lesser consequences, albeit it successfully contributed to the extermination of Semitic people. Another example of diminished complicity applies to Karol Wojtyla, who used liberation theology toward his native Poland by making a historic "liberating declaration" through the principle of solidarity (Cornwell, 2001: p. 52) which led to Poland's freedom from Soviet oppression. However, he disciplined Brazilian and Peruvian liberation theologians who wished to address poverty conditions of the people entrusted to their pastoral care, and he consistently ignored the oppression of archbishop Romero from El Salvador until this prelate was murdered (Kwitny, 1997) while celebrating the Eucharist.
} 
sus are the most important facets of human redemption. The nascent Jesus needed a woman, and the resurrected Jesus chose a woman to tell his story; in both instances women delivered and conveyed Jesus to the world. Jesus deliberately chose women despite the condition in which women lived in Jesus' era. They were considered male property and not reliable witnesses in licit proceedings (Daniel-Rops, 1962; Ketzer, 1978). Yet Jesus made women a sine qua non instrument of his human existence as well as his resurrection message. Time and again, Jesus selected women to challenge his contemporary traditions and to augment his redemptive mission. Perhaps Christians today ought to learn from Jesus' selection of women over men. If we were to synthesize Jesus' attitude toward women to teach others what being Christian means, we may premise it by claiming that where there is love, there is healing and forgiveness, but where there is no love, there is only condemnation and ridicule.

Certainly Jesus never addressed women's sexuality directly. Yet he did choose to adduce to men's co-participation in sexual activities (John 8: 7). Jesus did not condemn or ridicule either women or men for being sexually active (John 4: 18). Instead, only once throughout his life, Jesus chose an unmarried, sexually active woman to reveal unequivocally his divinity (John 4: 25-26). We can only wonder what his message may mean in today's society.

In contrast to Jesus' attitude toward sexually active and unmarried women, the bishops have argued that requiring religious employers to pay the costs of contraceptives, abortifacients, or sterilization violates the constitutional protection for religious freedom and it is similar to demanding "a kosher deli to serve ham sandwiches." This argument obviates the U.S. Catholic bishops' ignorance of women's sexuality (United States Conference of Catholic Bishops, 2012). It is insulting and ignorant; it not only minimalizes women's reproductive conundra within the spectrum of the limited choices we have discussed, it also singles women as beneficiaries of others' fiduciary responsibilities for their contractual employment benefits, (which is unreasonable because women have a property interest to contractual employment benefits), and it also demonstrates apathy (total lack of empathy and understanding), and condemnation of women due to their sexualities.

This inchoate "kosher deli" argument reminds us of the magisterium of 1st century Jerusalem who wished to condemn a woman to death because she was caught in the very act of adultery (but not the man). We wonder how the U.S. Catholic bishops may learn from the words and actions Jesus displayed on that occasion (John 8: 7-8). We also wonder how could the bishops have conscientiously helped to prevent the pressuring conditions adduced in Evangelium Vitae so that fewer women in 21st century America would have to choose to end unwanted pregnancies or to engage in birth control methods (see "reasons for seeking abortion” above).

\section{Conclusions and Recommendations}

Here, we have striven to remain within Catholic thought given that the U.S. Catholic bishops commenced this dialogue. However, we presume because Catholic theology does contribute to Christian dogmas, this dialogue may be amenable not only to Christians but also to other Abrahamic traditions in America.

Christianity originated as a diverging sect from Judaism. It proclaimed Jesus was/is the son of Yahweh. In particular the Catholic magisterium's authority draws from scriptures, tradition, and revelation; which originates in the words and actions of Jesus. Turning to Jesus' exemplary actions, we have discovered that he exalted women against the traditions of his time. Jesus never chose power, greed, or political ambitions. Instead Jesus showed kindness, sensitivity, and compassion to women, and treated them as equals to men, revealing only to a (fivetimes-married, sexually-active, unmarried-childless) woman his divinity (Girzone, 2009; Greeley, 2007; John 4: 26). These signs comprised his ministry, his redemption, and his legacy. Jesus manifested special interest in the weak, the poor, and the defenseless (Matthew 5: 1-11; Matthew 25: 36-36). Women in today's society continue to live in these conditions, and remain voiceless while Christianity conflates their womanhood with motherhood, leaving out the men who share their sexuality.

Human nature is very complex. To claim that God could have created a "better" world, or that humanity is intrinsically "flawed" has tremendous theological and scientific implications. It converts God's creative actuality into mere potentiality, and denies God's perfection and goodness. The world as we know it is just as God intended it to be, despite human errors. Herein lies however the perfection of the created order: A natural origin that has the potential for self-edification, or (unfortunately) self-destruction. But Jesus' Spirit has remained with humanity revealing truth to every human conscience (Paul VI, 1965a: § I.2; Matthew 28: 18-20).

Under the guidance of the Spirit we have advanced beyond what is written in scripture. But recognizing the Spirit's guidance requires humility to recognize, for example, that God cares particularly for the weak, poor, and defenseless. It is the hierarchy's responsibility to care for these seemingly insignificant members of the human family (Matthew 25: 43-40). This also requires reflection and constant prayer (Girzone, 2006). We mean the kind of prayer that asks for nothing from God, but that wonders what we each can do to bring about God's equanimous presence to earth (Luke 18: 9-14).

Because the Spirit informs every human conscience with glimpses of truth and goodness, conscience in turn is the foundation of free choices. We have adduced that freedom of conscience is therefore freedom of choice, and licitly these are human rights under constitutional protections in the 1st and 14th amendments in the U.S. Constitution. By contrast, moral abstractions and religious dogmas will never amount to civil law (Posner, 2002; Reynols v. U.S., 1878; Rowe v. Wade, 1973). Instead both theology and jurisprudence are built upon human patterns of behavior and on contributions from philosophy, anthropology, sociology, medicine, and all other forms of science. Science (from the Latin scientia, knowledge and understanding) is perhaps the true nexus between jurisprudence and theology that enables us to discuss women's reproductive needs under any healthcare provisions.

Essential to science are goodness and truth, which according to Catholic understanding emanate from God's own Spirit who guides the Church (John 16: 5-16). Ultimately, there is much to learn from Jesus' words and actions (Paul VI, 1965a: § I.2). The U.S. Catholic bishops' campaign against the Obama administration is aimed at taking away from women preventive services for their reproduction needs. Catholic women employees remain silent about this legal debate because of fear of losing both their modus vivendi and their share in the Eucharistic meal (which is contrary to Jesus' unequivocal mandate to share 
sacraments freely with everyone, see Matthew 10: 8). Statistics have revealed that contraceptive measures are negatively correlated to abortion incidence. Nevertheless women's access to contraceptives remains to be decided as a political issue by the stronger and richer members of society, placing women's freedom to choose outside the scope of civil and constitutional law.

We support women's right to free conscience which is their right to make free choices unburdened by any form of civil and religious coercion (Paul VI, 1965b: § I. 4). As mental health therapists we stand with women. We also remain loyal to women's rights, and respect their autonomy. We must provide them with therapeutic privacy where they can openly discuss their sexualities, their dreams, and interests. We recognize we need women to theorize about women. With few exceptions, only male scholars have developed the frameworks that constitute the systemic therapeutic paradigm. We need more women's contributions about what is therapeutic for them, and about their conceptions of God, their metaphysics beyond the realm of motherhood, and their epistemologies about what is licit regarding their sexualities and their reproductive choices.

We put forward crucial considerations to augment the spectrum of choices for women's reproductive decisions including: (a) ensuring women's healthcare needs are provided for by insurance companies; (b) ending discrimination of same-sex couples and enabling them to adopt the potential children who face potential material hardships but whose mothers remain willing to bring their pregnancies to term (for the Church's position against human discrimination, see Paul VI, 1965b: § I, 7); (c) ending sexual identity discrimination and promoting contraceptive use; (d) recognizing that motherhood and fatherhood must co-share child care responsibilities; (e) ending economic imbalances and enforcing equal income laws; (f) studying and addressing invisible disabilities that women may face; and $(\mathrm{g})$ recognizing that women wish to be educated in higher education and promoting their accessibility accordingly. Essentially, promoting equality among sexes in our society and in close intimate relationships may not only decrease abortion incidence, but it may also be instrumental in ending material hardships in our society (Meehan, 2011).

Doubtless, either liberals or conservatives will react to what is stated herein. Yet, however, unpleasant this discussion may appear to be, we believe as mental health therapists that these real issues pertaining to women's sexuality must be addressed openly.

We are not supporting dissent (or excommunication) but a realistic dialogue within which we must welcome the complications concomitant with a contemporary epistemology of female sexuality. Human ontology has deep implications ranging from theology to jurisprudence and to therapeutic theory and practice. The realities women face regarding their reproduction choices and rights must be discussed without guilt or fear of excommunication. These realities are not relativistic, functionalistic, merely secularist, or in any way subject to minimization and dismissal. Instead, these realities are complicated facets of human sexuality as originally created (Genesis 1: 27). We believe the self-corrective presence of conscience which is inherent to human beings has contributed to the evolution of Christianity over the last two millennia (Paul VI, 1964: $\S 7,50$ ). It is only by embracing this ongoing revelation about what it means to be human that we posit humanity may continue to remain an image of its Creator.

We close with a simple parable (on 24 June, 2012).
Once, there was a group of persons who differed from one another (by sex, religion, political affiliation, education, income, and so on). They were arguing about their sense of freedom. Next to them, there was a river and a cart full of non-persons, entrusted to their care. But as they continued to argue, they unattended the cart that kept filling up with non-persons; and it continued to tilt over unto the river, and one or two (out of every ten) non-persons fell into the river and drowned. Then, there came a moralist, a dogmatist, and an attorney. They saw what was happening. So they went and tried to rescue every non-person who fell into the river, but as they saved, perhaps, one non-person, another one or two non-persons would still drown. Then, there came woman. Woman saw and understood what was happening, but instead of helping the last three persons, woman went directly to the source of the problem and stopped it. And the non-persons did no longer drown, at least not as many. Finally, then came the "neutral" justices, and they changed everything.

\section{REFERENCES}

Ad Hoc Committee for Religious Liberty (2012). Our first, most cherished liberty: A statement on religious liberty. Washington: United States Conference of Catholic Bishops.

Anderson, R. T. (2011). Protected in law, cared for in life: The new health-care act fails to support pro-life principles. First Things, 215, 41-45.

Bennett, J. M. (2008). Forgetting the past. Gender \& History, 20, 669677.

Boushey, H., \& Gundersen, B. (2001). When work just isn’t enough: Measuring hardship faced by families after moving from welfare to work (Briefing Paper). Washington, DC: Economic Policy Institute.

Bradwell, V. (1872) Illinois. 83 U. S. 130, 137-138.

Bujalkova, M. (2007). Debate and education: Birth control in antiquity. Bratisl Lek Listy, 108, 163-166.

Charles, V. E., Polis, C. B., Sridharab, S. K., \& Blum, R. W. (2008). Abortion and long-term mental health outcomes: A systematic review of the evidence. Contraception, 78, 436-450.

Coleman, P. K., Coyle, C. T., Shupin, M., \& Rue, V. M. (2009). Induced abortion and anxiety, mood, and substance abuse disorders: Isolating the effects of abortion in the national comorbidity survey. Journal of Psychiatric Research, 43, 770-776.

Cornwell, J. (2001). Breaking faith: The Pope, the people, and the fate of Catholicism. New York: Penguin Putnam, Inc.

Cusack, S., \& Cook, R. J. (2009). Stereotyping women in the health sector: Lessons from CEDAW. Washington \& Lee Journal of Civil Rights \& Social Justice, 16, 47-78.

Daniel-Rops, H. (1962). Daily life in the time of Jesus: An authentic reconstruction of biblical Palestine and the day-to-day lives and customs of its people. New York: Hawthorn Books Inc.

Dixon, R., \& Nussbaum, M. (2011). Abortion, dignity and a capabilities approach. Chicago Public Law and Legal Theory Working Paper number 345. The Law School, The University of Chicago. http://www.law.uchicago.edu/academics/publiclaw/index.html

Dudley, S. (2003). Women who have abortions. In Abortion facts, National Abortion Federation. Retrieved from:

http://www.prochoice.org/about_abortion/facts/women_who.htm

Eisgruber, C. L., \& Sager, L. G. (2007). Religious freedom and the constitution. Massachusetts: Harvard University Press.

Federal Register (2012). Administration. 29 CFR Part 2590. RIN 1210-AB44. Department of Health and Human Services. 45 CFR Part 147. Group Health Plans and Health Insurance Issuers Relating to Coverage of Preventive Services under the Patient Protection and Affordable Care Act. http://www.gpo.gov/fdsys/pkg/FR-2012-02-15/pdf/2012-3547.pdf

Finer, L. B., Frohwirth, L. F., Dauphinee, L. A., Singh, S., \& Moore, A. M. (2005). Reasons U.S. women have abortions: Quantitative and 
qualitative perspectives. Perspectives on Sexual and Reproductive Health, 37, 110-118. doi:10.1363/3711005

Fischer, J. M. (2010). Precis of my way: Essays on moral responsibility. Philosophy and Phenomenological Research, LXXX, 229-241. Riverside, CA: Philosophy and Phenomenological Research, LLC. doi:10.1111/j.1933-1592.2009.00320.x

FoxNews.com (2012). Minorities now surpass whites in U.S. births, census shows. FoxNews.com, Politics.

http://www.foxnews.com/politics/2012/05/17/minorities-now-surpas s-whites-in-us-births-census-shows/\#ixzz1yiKHt4pT

Girzone, J. F. (2006). My struggle with faith. New York: Doubleday.

Girzone, J. F. (2009). Jesus: A new understanding of God's son. New York: Doubleday.

Gisin, N. (2010). Are there quantum effects coming from outside spacetime? Nonlocality, free will and "no many-worlds". Geneva, Switzerland: Group of Applied Physics, University of Geneva.

Greeley, A. (2007). Jesus: A meditation on his stories and his relationships with women. New York: Tom Doherty Associates, LLC.

Greeley, A. (1979). The making of the popes 1978: The politics of intrigue in the Vatican. Kansas City, KA: Andrews and McMeel, Inc.

Green, M. H. (2008). Gendering the history of women's healthcare. Gender \& History, 20, 487-518. doi:10.1111/j.1468-0424.2008.00534.x

Grisez, G. (1983). The way of the lord Jesus: Christian moral principles. Chicago: Franciscan Herald Press.

Guttmacher Institute (2011). Abortion. Fact sheets: Facts on induced abortion in the United States.

http://www.guttmacher.org/sections/abortion.php

Heflin, C. H., \& Butler, J. S. (2012). Why do women enter and exit from material hardship? Journal of Family Issues. Published Online 11 April 2012. doi:10.1177/0192513X12442822

Hennette-Vauchez, S. (2011). A human dignitas? Remnants of the ancient legal concept in contemporary dignity jurisprudence. Oxford University Press and New York University School of Law, 9, 32-57.

House Office of Legislative Counsel (2010). The patient protection and affordable care act of 2010.

http://housedocs.house.gov/energycommerce/ppacacon.pdf

Jesani, A., \& Iyer, A. (1993). Women and abortion. Economic and Political Weekly, 27 November 1993, 2591-2594.

John Paul II (1995b). Evanvelium vitae.

http://www.vatican.va/holy_father/john_paul_ii/encyclicals/documen ts/hf_jp-ii_enc_25031995_evangelium-vitae_en.html

John Paul II (1995a). Letter of Pope John Paul II to women. Boston: St. Paul Books and Media.

John Paul II (1988). Mulieris dignitatem.

http://www.vatican.va/holy_father/john_paul_ii/apost_letters/docum ents/hf_jp-ii_apl_15081988_mulieris-dignitatem_en.html

Joffe, C. (2009). Abortion and medicine: A sociopolitical history. Management of Unintended and Abnormal Pregnancy, 10, 1-9. doi:10.1002/9781444313031.ch1

Katz, S. N. (2011). Family law in America. New York: Oxford University Press.

Kertzer, M. N. (1978). What is a Jew? New York: Collier Books.

Kimport, K., Foster, K., \& Weitz, T. A. (2011). Social sources of women's emotional difficulty after abortion: Lessons from women's abortion narratives. Perspectives on Sexual and Reproductive Health, 43, 103-109. doi:10.1363/4310311

Kwitny, J. (1997). Man of the century: The life and times of Pope John Paul II. New York: Henry Holt and Company.

Major, B., Applebaum, M., Beckman, L., Dutton, M. A., Russo, N. F., \& West, C. (2009). Abortion and mental health: Evaluating the evidence. American Psychologist, 64, 863-890. doi:10.1037/a0017497

Meehan, M. (2011). Why should liberals defend the unborn. Human Life Review, 15-30.

Mortensen, O., Torsheim, T., Melevik, O., \& Thuen, F. (2012). Adding a baby to the equation. Married and cohabiting women's relationship satisfaction in the transition to parenthood. Family Process, 51, 139. doi:10.1111/j.1545-5300.2012.01384.x

O’Brien, J., \& Major, W. (1982). In the beginning: Creation myths from ancient Mesopotamia, Israel and Greece. The American Academy of Religion. Number 11.

Otterman, S. (2012). Dolan says Obama policies threaten "Sacred Liberties". The New York Times, NY/Religion.

http://www.nytimes.com/2012/06/23/nyregion/obama-mandate-threa tens-sacred-liberties-dolan-says.html?ref=health

Paul VI (1968). Humanae vitae.

http://www.vatican.va/holy_father/paul_vi/encyclicals/documents/hf _p-vi_enc_25071968_humanae-vitae_en.html

Paul VI (1965b). Dignitatis humanae.

http://www.vatican.va/archive/hist_councils/ii_vatican_council/docu ments/vat-ii_decl_19651207_dignitatis-humanae_en.html

Paul VI (1965a). Dei verbum. http://www.vatican.va/archive/hist_councils/ii_vatican_council/docu ments/vat-ii_const_19651118_dei-verbum_en.html

Paul VI. (1964). Lumen gentium.

http://www.vatican.va/archive/hist_councils/ii_vatican_council/docu ments/vat-ii_const_19641121_lumen-gentium_en.html

Pham, J. P. (2004). Heirs of the fisherman: Behind the scenes of papal death and succession. New York: Oxford University Press, Inc.

Posner, R. A. (2002). The problematics of moral and legal theory. Cambridge, MA: The Belknap Press of Harvard University Press.

Potts, M. (1967). Legal abortion in Eastern Europe. Eugenics Review, $59,232-250$.

Reindhardt, U. E. (2012). Awaiting the Supreme Court's healthcare ruling. The New York Times, Economix: Explaining the Science of Everyday Life.

Reindhardt, U. E. (2012). The Supreme Court and the national conversation on health care reform. The New York Times, Ecomix: Explaining the Science of Everyday Life.

Reynolds v. U. S., U. S. 145 (1878).

Rhoda, A. (2007). The philosophical case for open theism. Philosophia, 35, 301-311. doi:10.1007/s11406-007-9078-4

Rovner, J., Totenberg, N., Frick, A. (2012). Countdown to the Supreme Court's ruling on health care. National Public Radio. Weekend Edition Sunday.

Rowe, V. Wade, 410 U. S. 113 (1973).

http://www.npr.org/blogs/health/2012/06/24/155596355/countdown-t o-the-supreme-courts-ruling-on-health-care

Shah, I., \& Ahman, E. (2009). Unsafe abortion: Global and regional incidence, trends, consequences, and challenges. Journal of Obstetrics and Gynaecology Canada, 31, 1149-1158.

Svetlichny, G. (2012). How free will could will. History and Philosophy of Physics, 1-11.

Torfs, R. (2011). The internal crisis of religious freedom. International Journal for Religious Freedom. 4, 17-27.

U.S. Census Bureau (2012b). U.S. statistical abstract, 2012. http://www.census.gov/compendia/statab/

U.S. Census Bureau (2012a). 2010 Census data. http://2010.census.gov/2010census/data/

United States Conference of Catholic Bishops (2012). Bishop Lori tells parable of the kosher deli and the pork mandate in congressional testimony, 16 February 2012. Conscience Protection.

http://usccb.org/issues-and-action/religious-liberty/conscience-protec tion/index.cfm

Wertenbroch, K., Vosgerau, J., \& Bruyneel, S. D. (2008). Free will, temptation, and self-control: We must believe in free will, we have no choice (Isaac B. Singer). Journal of Consumer Psychology, 18, 27-33. doi:10.1016/j.jcps.2007.10.006

Wildsmith, E., Guzzo, K. B., \& Hayford, S. R. (2010). Repeat unintended, unwanted and seriously mistimed childbearing in the United States. Perspectives on Sexual and Reproductive Health, 42, 12-22. doi:10.1363/4201410

Yip, A. K.-T. (2010). Special feature: Sexuality and religion/spirituality. Sexualities, 13, 667-670. doi:10.1177/1363460710384555 